DOI: $10.19195 / 0137-1150.163 .46$

\author{
IVA MÁLKOVÁ \\ Ostravská univerzita v Ostravě, Republika Czeska \\ iva.malkova@osu.cz
}

\title{
Motivy a témata stáří a smrti v básnickém a prozaickém díle Františka Hrubína
}

Jedním ze znaků poezie, prózy i dramatu Františka Hrubína (1910-1971) — jedinečné tvůrčí osobnosti české literatury 20. století — je jistota vycházející z poznání vlastních kořenů. K nim patř́ jeho rod, děti, které se do něj rodí, dospívají a stárnou, mrtví, kteří určují jeho identitu.

Pokusíme se pročítat a promýšlet ve výkladech, vlastně v několika interpretačních vhledech, básnické a prozaické dílo Františka Hrubína ve vztahu k motivům stáří a smrti. Budeme vnímat stáří nejen jako sénium — poslední etapu v ontogenetickém vývoji člověka, jako závěr lidské pozemské existence, ale také chronologicky, jako věk, jako postupné trvání pobytu člověka na zemi od zrození po smrt.

Předcházející badatelská činnost mi dala možnost poznávání díla F. Hrubína do hloubky a ve všech vrstvách (rukopisy, časopisecké otisky, varianty v knižních vydáních), ${ }^{1}$ přesto čtenářský návrat zvláště $\mathrm{k}$ básnickým a prozaickým textům prizmatem tématu stáríi a smrti byl opět inspirující.

Při vymezení tématu stati se ihned asociují básnické sbírky a prózy Františka Hrubína, kde se stáří a smrt tematizují pro českou literaturu až kanonicky, ale přesto se pokusíme připomenout vedle „klasických” souvislostí i některé neotřelé.

I dnes se jako směrodatná jeví určení, jimiž vymezil Hrubína jako autora i jeho poetiku po vydání prvotiny (to se ocitáme v roce 1933) František Xaver Šalda: „Tichý extatik, který vidí, co uniká jiným: barvy a tóny ultrafialové; mámivý melodik, tím mámivější, že melancholický zpěv jeho krve láme do zajíknutí touha duchovnosti a lítost nevykoupení. Vztahy na samém pomezí nevyslovitelna, subtilní nápovědy života a předtuchy smrti jsou vlastní doménou Františka

${ }^{1}$ F. Hrubín, Básně, [w:] Adresát František Hrubín. Dopisy F. Hrubína, J. Seiferta, J. Strnadla, E. Frynty, ed. I. Málková, Brno 2010; I. Málková, František Hrubín. Z archivních fondi̊, Brno 2011. 
Hrubína."2 Fyziognomie básnického JÁ ve sbírkách Františka Hrubína počítá od počátku své existence se stářím, poznamenává a předznamenává se věkem — sílí vráskami jako strom letokruhy.

Tvár̆ si letům zvyká

jako krokům tráva,

z dlouhých cest jak z vlasů tma vás vyčesává. ${ }^{3}$

Oblaky se přes nás ženou,

ved' nás $\mathrm{k}$ zemi bez hoře

ještě dnes

a tu dálku nespatřenou

oráč smrti přioře

jako mez! ${ }^{4}$

myslím si, ty vrásky kolem úst

ryl jsem ti trochu snad ostře. ${ }^{5}$

Ukládání minut a hodin, přibývání prožitků, narůstání času, který určuje, ovlivňuje záznam vlastního tlukotu srdce, melodií a vůní, které nás obklopují, a tak znamenají, patří k tvorbě Františka Hrubína neodvolatelně.

To je omamné vnímání času, zrání, stárnutí básníkem. Jeho pohled a rozum se stále ubírají vpřed, jeho touhy však chtějí zadržet čas, aby prožitek určité fáze života byl ten nejhlubší, aby emocionální naplnění dostoupilo vrcholu, aby se ustrnutím jedinečné chvíle života zjevilo vše nevýslovné, aby se v ní zračilo poznání „nesmírné krásy života”, aby se individuální a prézentní prostoupilo s lidským rodem a pradávnem.

Živote, postůj, já jsem tvůj, mám ústa, oči, noc a řeku, miluji, vidím, hořím, teku, radostem pláč můj obětuj, na čelo polož vrásku k vrásce,

dej rty mé nocím, smrt mou lásce! ${ }^{6}$

Takto se Hrubín vyznával, takto žádal, aby byla oslabena pomíjivost života. Znovu se v poslední básni jeho prvotiny Zpíváno $z$ dálky presvědčujeme, jak blízko jsou si motivy času, věku, lásky a smrti. Jako ozvěnou, stejnými slovy s připomenutím doby vzniku (sloka ze srpna 1933), otevírá Hrubín za téměř třicet let svou sbírku Až do konce lásky (1961). Úžas nad životem a prožitky trvá — prosbu posečkání ted' už zralý a znovu uznávaný básník ještě umocňuje, stáří zesiluje váhu a význam kaž-

${ }^{2}$ F.X. Šalda, Pohled na naši nejnovější produkci básnickou, [w:] idem, Šaldův zápisník, svazek 6, 1933-1934, Praha 1993, s. 30-31.

${ }^{3}$ F. Hrubín, Zpěv noci, [w:] Básnické dílo I, (sbírka) Zpíváno z dálky, Praha 1967, s. 42.

${ }^{4}$ F. Hrubín, Prosba, [w:] Básnické dílo I, (sbírka) Zpíváno z dálky, s. 56.

${ }^{5}$ F. Hrubín, Píseñ pro ženu, [w:] Básnické dílo II, (sbírka) Cikády, Praha 1968, s. 104.

${ }^{6}$ F. Hrubín, Slzy sv. Vavřince, [w:] Básnické dílo I, (sbírka) Zpíváno z dálky, s. 61. 
dého okamžiku. Básnický subjekt rekapituluje i projektuje svůj život a provazuje jej s prvky, kterými je dnes vymezována pozitivní psychologie. ${ }^{7}$ Ta sehrává podstatnou roli při charakteristice prvků označujících možnou kvalitu závěrečné fáze lidského života. ${ }^{8}$ Láska a vděčnost, odpuštění a smiřování se snoubí s hlubokým ponorem do každé dělné chvíle života, s vědomím, že každá činnost je naplňující.

Živote, postůj,

tohle je jistě ta chvíle chvil,

všechno, co jsem do tebe zasil, všechno, pro co jsem žil,

pro tuhle chvíli zrálo — živote, postůj tedy,

všechno vidím jako poprvé, jako naposledy.

Živote, postůj,

tohle je jistě ta chvíle chvil!

Ted' musíš stanout!

Kdyby ses pohnul, čím bych dál žil?

Živote, postůj,

dám ti všechno, celou svou bytost,

postůj, máme poslední př́ležitost!

Živote, díky, žes nestál!

Z každé chvíle se rodí tisíce nových chvil.

Kdybych byl stanul, byl bych mrtev, nebyl bych žil.

A žiji jen proto, že jsem nikdy a nikde neměl stání.

I ona chvíle pukla žárem, díky, žes nestál, díky ti za ni! ${ }^{9}$

Citace $\mathrm{z}$ básnických sbírek Františka Hrubína naznačily, že básnický subjekt vnímá a zažívá vlastní stáří / věk ve chvílích citové extáze, ale se vždy př́itomným vědomím, že zrození a smrt patř́i k sobě, že stáří přibývá den po dni, spoluurčuje pobyt člověka při pozemské pouti. Básně prostupuje také prožívání blízkosti lásky a smrti, štěstí a úzkosti. ${ }^{10}$

Přehlížíme-li uzavřené dílo Františka Hrubína s odstupem, nacházíme motivy, které potvrzují, že mrtví byli vždy součástí tematických celků, v nichž se zobrazuje povaha lidského života. ${ }^{11}$ Ve válečné sbírce Mávnutí křídel (1944) bás-

${ }^{7}$ Pozitivní psychologie zahrnuje témata z oblasti kognitivní (moudrost, naděje, optimismus), z oblasti emocí (flow-fenomén, emociální inteligence, kladné sebeoceňování), témata sociální psychologie (vděčnost, láska, odpuštění, smiřování), zvládání životních situací (humor, připomínání si kladných zážitků, spiritualita).

${ }^{8}$ L. Zdražilová, Determinanty tvořivé činnosti ve stáří, Diplomová práce, Brno 2007.

${ }^{9}$ F. Hrubín, Srpnové poledne, [w:] Básnické dílo V, (sbírka) Až do konce lásky, Praha 1969, s. 95-96.

10 „Daleké hvězdy umí člověk zvážit, / ale svou lásku nikdy nezváží — // a jako před smrtí je před ní němý. /" (F. Hrubín, Básníkův návrat, [w:] Básnické dílo II, (sbírka) Země sudička, Praha 1969, s. 89.) „Tenkrát jsem slyšel cikády / vzlykat jen — láska, láska... / ale ten vzlyk tak léty ztvrd, / cvrčkové, že se zajíkáte, / když zpíváte a naříkáte, / že je tu ještě smrt, / že je tu ještě smrt... //" [...] (F. Hrubín, Cikády, [w:] Básnické dílo II, (sbírka) Cikády..., s. 95).

11 „A jejich žízeň? Přelila se / z těch mrtvých srdcí do našich... //” (F. Hrubín, Cikády, [w:] Ibidem, s. 96). 
nické JÁ, tolik blízké fyzickému básníkovi, charakterizuje své bytí veršem „můj láskou, smrtí, opojený život, ${ }^{\prime \prime 12}$

Z hluboké lásky k životu

naplnil jsem svou samotu

mrtvými, kteří naslouchají

cikádou v nocích srpnových,

zda zpívám, nebo zda jsem ztich,

úzkostně vyzvídají v máji. ${ }^{13}$

V roce 1960, když píše Hrubínovi k jeho padesátinám, se Bedřich Fučík ohlíží za Hrubínovou básnickou poutí, hodnotí její jednotlivé etapy, zastavuje se u proměn, u planých a silných veršů jeho sbírek a potvrzuje význam motivu smrti v básníkově díle. Píše: ,[...] byl jsem smuten nad každým mávnutím křídel naprázdno, a uklidnil jsem se, když jsi navázal se svými mrtvými." 14

Jedno z vymezení stáŕí akceptuje perspektivu dětí — vnuků, tedy starým se stává ten, kdo představuje generaci prarodičůn, kdo sdílí život s vnuky. Tuto dimenzi také nacházíme mezi verši Františka Hrubína výrazně. V okamžicích, kdy se vrací ke chvílím smrti svého dědečka, děje se tak na prahu druhé světové války, píše v sonetech verše, kde poprvé tematizuje vědomé pokračování rodu i po odchodu jeho nejstaršího člena. „Nad hrobem tvým se modlím. [...] Poznáváš se v mém stínu [...] Nad hrobem tvým se modlím, já — tvůj vnuk. /"15 „Od hrobu zpátky podle žit / slyším tvůj krok podle mého kroku, /"16 „Jdeš na úmrtní lůžko spát / a pamět' rodu ve vánici tváŕí / vločku tvé tváře chvátá vyhledat — /"17

Takové obrazy můžeme vnímat, nejen díky nápovědě v předposledním verši, jako místa paměti, jak je vymezuje Pierre Nora. ${ }^{18}$ Usazenina pocitů, společných prožitků, paralelita já — ty je rozhodující pro vyjádření kontinuity. Místa paměti básnického já však nejsou součástí traumatu, naopak můžeme obrazy interpretovat, jako záznamy osobní paměti čelící dobovému historickému traumatu.

Pozoruhodnými tématy v Hrubínově poezii jsou kontrast i prostoupení - muže a dítěte, starce a chlapce. Na nejrozsáhlejší básnické ploše vnímáme tuto dvojjedinost i protikladnost v Proměně (1957), kdy v paralelitě sledujeme minipř́íběh starce a chlapce na břehu řeky během jednoho letního dne a mýtické události spojené s osudy Daidala a Ikara. V básnické sbírce, která uvozuje z hlediska tvůrčího

${ }^{12}$ F. Hrubín, Housle a ruka, [w:] Básnické dílo II, (sbírka) Mávnutí křidel, Praha 1968, s. 157.

${ }^{13}$ F. Hrubín, Vesmír, [w:] Básnické dílo II, (sbírka) Cikády..., s. 115.

${ }^{14}$ Citováno podle I. Málková, František Hrubín..., s. 37-38. (Dopis byl napsán 17. září 1960).

15 F. Hrubín, Včeli plást, [w:] Básnické dílo II, (sbírka) Včelí plást, Praha 1968, s. 39.

16 Ibidem, s. 40.

${ }^{17}$ Ibidem, s. 41.

18 „Okamžik klíčový, v němž se vědomí rozchodu s minulostí mísí s pocitem rozervané paměti; kde však tato trhlina probouzí ještě dost paměti na to, aby mohl být nastolen problém jejího vtělení. Pocit kontinuity se stává usazeninou, shromážděnou v určitých místech. Místa paměti existují proto, že už neexistují prostředí paměti." P. Nora, Mezi pamětí a historií, [w:] Problematika mist. Politika paměti, ed. F. Mayer, 2012, NO 13, s. 8. 
Hrubínova vrcholná šedesátá léta, Až do konce lásky (1961), rozporuplnou pozici fyzického a psychologického stáŕí prožívá básnické JÁ v básni Každou vteřinu.

[...] Kdosi mě volá:

Stárnoucí muži!

A ozvěna opakuje:

Muži!

Ale já z blikajících světýlek noci čtu:

Chlapče!

Jaký to má smysl?

Sedím u tatínkova li̊žka, umírá,

drží mi ruku a chce mé slovo a můj úsměv,

v jeho očích je tolik bezelstné bezmoci,

že všechna něžnost, kterou cítím k dětem,

protlačí se mi z nitra naráz

a on ji zachytí v mých očích,

jsou jí plny,

ani pro slzu slzy v nich není místa:

ta poslední vteřina

je vteřinou podivného štěstí nás obou.

Jaký to má smysl? [... $]^{19}$

Stejně tak se v básni Syrinx básnické JÁ utvrzuje, že stáŕí fyzické a psychologické jsou dvě různá hlediska:

Oba, muž i chlapec, jdou v jednom těle. / Mají dohromady jedno srdce. / Muž cítí, jak to srdce je strašně sevřené, / bolestně cítí, jak chlapcova touha / př́bojem bije do jeho stěn. // [...] Ale kdyby muži puklo srdce, / chlapec by padl mrtev. // [...] Nebot' kdyby zašel chlapec v muži, / nic by nezbylo z lásky, / nic by nezbylo z poezie. ///20

Abychom chápali zdroj a povahu Hrubínovy obraznosti, jíž zachycuje prostupování základních etap lidského života, dětství — dospělosti — stáríi, musíme se ještě jednou vrátit na počátek, tentokráte nikoli básnické cesty, ale na počátek života Františka Hrubína.

V roce 1914 začíná první světová válka, rodina Hrubínových žije ve Františkově rodišti, v Praze, ale narukování tatínka do rakousko-uherského vojska všechno změní. Maminka vezme obě tehdejší děti (Františkovi jsou 4 a Josefovi 2) a odstěhuje se do Lešan — obce nedaleko řeky Sázavy, sousedící s obcí Břežany, která byla Františkovou domovskou, s Netvořicemi, s vrchy Bensovou a Běsnou poblíž.

Františka obklopí nejen příroda, rytmus každodenní práce, ale především jeho vlastní rod s moudrostí, se zálibou v knihách a prastarých kalendář́ích, $\mathrm{s}$ dělností dědečků, strýců a tetiček. Dětství a stáří mu splynou do nerozdělitelného prožitku. Lešany a lešanská chalupa se stanou vesmírným prostorem, básnickým

${ }^{19}$ F. Hrubín, Každou vteřinu, [w:] Básnické dílo V, (sbírka) Až do konce lásky..., 1969, s. 133134.

${ }^{20}$ F. Hrubín, Syrinx, [w:] Básnické dílo V, (sbírka) Až do konce lásky..., s. 127-130.

Slavica Wratislaviensia 163, 2016

(C) for this edition by CNS 
prostorem, kde se navždy (pro všechny jsoucí a budoucí čtenáře) budou odehrávat dramata a poznávání. Tady se budeme opakovaně a v transformacích loučit s prvním i s druhým milovaným dědečkem (Včeli plást, 1940; Doušek života, 1949; U stolu, 1958 - Romance pro kř́llovku, 1962), s maminkou (Černá denice, 1968). Stáŕí a smrt nás budou učit hodnotám lidského života, budou se dotýkat našich nejistot a jistot, tužeb a naplněných přání.

Smrt dědečka očima chlapce (Včelí plást, Doušek života, U stolu) představuje jeden z nejsilnějších Hrubínových obrazů v poezii i próze — blízkost a vzdálenost smíchu a pláče, smutek a hrdost a zvládání podivného a doposud nepoznaného tajemství hranice bytí a nebytí, reality a vzpomínky, fyzické přítomnosti a nehmotného a nehmatatelného duchovního spříznění.

Jednou v noci mě probudil maminčin hlučný smích. Posadil jsem se na posteli — a směji se také. To je jistě dědečkovi lépe. Ale proč tak pozdě ještě svítí lampa? Probouzím se docela. Tatínek mě se slzami v očích vede k dědečkově posteli. Maminka se nesmála, jak se mi zdálo, ale plakala a štkala tak, jak jsem ji před tím nikdy neslyšel. [...] Druhého dne od rána leží dědeček v malé seknici, kde se nikdy nebydlilo a která byla trochu také sýpkou. Ještě než odzvonily hrany, přicházejí do světničky př́buzní a známí, by naposled viděli dědečkovu tváŕ. [...] $\mathrm{S}$ každým novým hostem vcházím za dědečkem. Pyšně se $\mathrm{k}$ němu hlásím před dětmi sousedů, rovnám mu vlasy a šaty. Smráká se. Únorový den bez sněhu svezl se posledním světlem po tváři nebožtíkově. [...] Večer síň a světnice ztichly. Ale na nebožtíka se vzpomíná v celé vsi. Dědečkovo jméno, po prvé množstvím současně vyslovované, obléhá nepostižitelným vlněním naše stavení. U nejbližších příbuzných a sousedů rozsvěcují za mrtvého svíčky.

Každou chvíli si jdu do studené malé seknice, chladnější o chlad nebožtíkův, pro knížku do své knihovničky u nohou mrtvého. Nečtu, ale knížky stále vyměňuji, abych se mohl znova a znova na dědečka dívat. Světlo svíce u hlav nebožtíkových přechází od zavřených očí přes propadlé tváře k vysedlé bradě. Zdá se mi, že je dědeček mladší. Vrásky se vyhladily. Cítím, že jsme ještě většími práteli než za jeho života. Kdykoli se trochu déle zdržím u mrtvého, přichází maminka. Dělám dědečkovi kříž na čele, na ústech a na prsou a pak chvatně, mlčky sahám po knížce, jako bych byl vyrušen z rozmluvy velmi důvěrné, z níž nesmí ani maminka nic slyšet. $[\ldots]^{21}$

Známe i variantu a transformaci obrazu — smrt dědečka očima chlapce a to smrt dědečka očima mladého muže (Romance pro kř́llovku).

Z životopisu básníka víme, že jako student gymnázia v roce 1929 přerušuje studium a stará se o dědečka postiženého mozkovou mrtvicí, po jeho smrti se ke studiu vrací.

Mladý muž si jasně uvědomuje své stáŕí, je synem i vnukem, je stejně tak na konci rodového řetězce, je tím, kdo prostřednictvím životů tatínka a dědečka, prostřednictvím jejich podnětů vyzrává, současně v básni s mnoha časovými rovinami přehlíží události již z perspektivy otce a děda.

Romance pro kř́ldlovku zpřítomňuje obřady, které jsou prostoupeny motivy s významem stáří a smrti (holení břitvou, omývání a převlékání mrtvého), stávají se přirozenou součástí obyčejného života a současně jej pozdvihují k mýtu.

${ }^{21}$ F. Hrubín, Doušek života, Praha 1949, s. 40-46. 
Soužití $\mathrm{s}$ dědečkem provázej v této básni obrazy hluboké lásky, pochopení i mladické netrpělivosti. Vnuk vstupuje do dědečkova světa, kde žijí dávno mrtví druhové, hraje při procházkách a nočních vytrženích jejich role, láskyplně chodí pokojem, jako by putoval krajinou k nádraží, jel vlakem, vystupoval a blížil se k domovu. ${ }^{22}$ Právě pravidelná zvolání dědečka „Domů!” v sobě nesou dvojí významové směřování (pokud budeme vnímat Hrubínovo dílo v celku). Výkřik se vztahuje nejen k prostoru současného života, který ochraňuje, ale také k rodovému společenství, to je utvářeno, přetvářeno, posilováno nejen všemi živými, ale také všemi mrtvými. Obrazy setkávání, přátelských promluv, ulpívání na obyčejných slovech, v nichž je ukryta moudrost i vyznání, se stávají nepatetickým vyjádřením životních hodnot. Jsou podnětem k přemítání nad minulým životem — prolínají se časové roviny, prostupují se časy příběhu a čas „,vyprávění” (1933, 1934, 1962). Toto přemítání patř́i nejen tomu, kdo má roli syna a vnuka, ale i tomu, kdo se mezitím stal otcem i dědečkem. Emocionální prožitky jsou zachyceny sugestivními obrazy, které voní, zní, mají haptickou i kinetickou sugesci, opakují se, variují se a jsou transformovány jako stř́pky, v nichž je ukryto tajemství, zákonitost dobrého a smysl majícího lidského života.

Dědečkovo odcházení se snoubí s erotickými prožitky básnického subjektu s Tonkou i s platonickým okouzlením Terinou, je v sousedství se žárlivostí na Viktora, které dvacetiletý básnický subjekt prožívá. Dynamika se sráží i vyvažuje s poklidem, současnost a aktualita jsou zpochybňovány i potvrzovány dávným časem i existencí, kdy je smazána a nepodstatná posloupnost splývajících okamžiků. Vědomí stáŕí vyvažuje úzkost, děsivost snů. Poznávání mnohosti a překonávání smrti vytváŕí básnické (at' vyjádřeno verši, prózou, dramatem, esejem) poselství o neuchopitelné a závratné kráse lidského života.

Setkávání se smrtí současně skokově proměňuje „sociálně-historický” věk básnického JÁ, dochází ke změně sociálních rolí. Chlapec se mění v muže, v hierarchii rodu se odchodem děda proměňuje jeho pozice. Opakovaně zaznívá citát z Ovidia, ${ }^{23}$ zpř́ítomňující ozvěna mající význam úzkostného mementa (už jsme jej prožívali v lešanské světnici, když umřel první dědeček, když se všichni stra-

22 „Dědečkovi / bylo by napřesrok osmdesát let. / Byl po mrtvici. Denně za svítání / jsem ho pomalu oblékal, s ustavičným / domlouváním jako dítěti, od ponožek / až k šátku na krk. Slyšel každé slovo / z našeho světa, ale hned je zapomínal. [...] Den po dni / mrtví vystupovali z limbů a za ně / jsem mluvil já. Často jsem se tou hrou i bavil, / musel jsem se přece bránit, i když stále / mezi mým a jeho prostorem šuměla / purpurová stěna mé mladé krve, / [...] Přes jedno rameno / přelévají se mi teplé vůně kopřiv, / druhé zamrzá v černých ledech světnice. /" (F. Hrubín, Romance pro kř́dlovku, [w:] Básnické dílo V, (sbírka) Romance pro kř́dlovku, Praha 1969, s. 150-151. ,Jsem k zbláznění živý, / má křŕdla, zřasená v krvi žil a cév, / šíleně tepají. //” (ibidem, s. 153), „[...] a je to noc všech nocí, prvně v žití nesu / strašné břímě lásky a smrti současně, / a sladko je mi nést je, navždycky třeba, / i s tím mrazením i s tím šikováním / k dlouhým a drsným bitvám o život ve mně. //" (ibidem, s. 158)

${ }^{23}$ Lyricko-epickou skladbu uvozuje motto z Ovidiových Proměn: „Velké věci si žádáš, ten dar je nad tvoje síly, / Fäthonte, tvůj chlapecký věk jej nemůže zmoci. / Smrtelný jsi, však není smrtelné, čeho si přeješ. //" (ibidem, s. 139). 
chovali o život otce na frontách první světové války — tato echa vytváří zásadní pamětovou, emociální stopu).

Tenkrát jsi netušil, že mi třeba dáváš / dar nad mé síly, jako jsem netušil já, / že zaslechnu až za šestadvacet let / šelest popela, jenž sesypal se náhle / na žhavém konci doutníku, když mi ze rtu / vytryskla pod břitvou kapička krve / a ty ses polekal a prudce trhl rukou, / za šestadvacet let, až na jaře přijdu / k tvému čerstvému hrobu a spatřím tam / kvést jako první rostlinu zlatý kopr, / poroste zrovna z těch hlubokých míst, / kde jsou tvá ústa, a z vysokého stonku / bude se smát všem neživým uschlým věncům. //24

Díla, u nichž jsme se zastavili, Včelí plást, Doušek života, U stolu, Romance pro kř́llovku, v obrazech soužití starce a vnuka zachycují skutečnosti, kterými bývá stáŕí $\mathrm{v}$ teoretických, psychologických, zdravovědných a dalších publikacích vymezováno - návrat $\mathrm{k}$ prožitým zážitkům, přemítání nad minulým životem. Vnuk díky hluboké lásce $\mathrm{k}$ dědečkovi, díky podvědomému chápání vlastních kořenů, utváří vlastní charakter, který je opět svázán s rodem a odpovědností za něj (byt' se to přirozeně bije s dětskou a mladickou touhou a nespoutaností — např. prožitky milostného opojení a metaforizace euforie za pomocí krve a křídel v Romanci pro kř́llovku).

Hrubínovy básně, prózy, vzpomínky utvářejí rodovou kroniku, jako bychom listovali rodinným albem. Není vůbec podstatné, jakou mírou jsou kronika i album autobiografické, protože obrazy extází - melodických, milostných, žalostných, radostných, bolestných — obrazy okouzlení a úžasu se stávají přemítáním nad životem. Hrubínova tvorba je od počátku prostoupena prvky, které patří k zralému věku, které ale lyrickým subjektům nebrání dělat chyby, zklamávat, trápit sebe i druhé, prohrávat i mít naivní sny a jít za nimi bezhlavě. Stáří je plod, z něhož básnické JÁ stále uždibuje, které přikusuje v každém věku a přirozeně se přitom setkává se smrtí.

V Hrubínových básních a prózách vnímáme gesta mající povahu nábožných opakování toho, co se dělá od věků, prožíváme v nich také tělesnou totožnost úkonu a smyslu. Při čtení Hrubínova díla dochází k obnovování paměti (rodové paměti, kdy rodem je rod člověčí), místa paměti se stávají místem záchrany, i když jej už neobýváme (viz Nora). Mnohé události, prožitky (mj. ty spojené se stárím, se smrtí) se v průběhu Hrubínovy tvorby opakují, v opakováních transformují a evokují podobu paměti jako věčné přítomnosti. Texty obnovují pamět', jako to zvládají mýty a legendy, a tak nabývají jejich žánrové rysy.

\section{Bibliografie}

Adresát František Hrubín. Dopisy F. Hrubina, J. Seiferta, J. Strnadla, E. Frynty, ed. I. Málková, Brno 2010.

Hrubín F., Básně, ed. I. Málková, Brno 2010.

Hrubín F., Básnické dílo I, Zpíváno z dálky, ed. J. Brabec, Praha 1967.

${ }^{24}$ Ibidem, s. 143-144. 
Hrubín F., Básnické dílo II, Země sudička, ed. J. Brabec, Praha 1968.

Hrubín F., Básnické dílo V, Můj zpěv, ed. J. Brabec, Praha 1969.

Hrubín F., Doušek života, Praha 1949.

Málková I., František Hrubin. Z archivních fondi̊, Brno 2011.

Nora P., Mezi pamětí a historií, [w:] Problematika míst. Politika paměti, ed. F. Mayer, 2012, NO 13.

Šalda F. X., Pohled na naši nejnovějši produkci básnickou, Šaldův zápisník, svazek 6, 1933-1934, Praha 1993.

Zdražilová L., Determinanty tvořivé činnosti ve stáří, Diplomová práce na FF MU v Brně, vedoucí práce: prof. PhDr. J. Švancara, CSc., Brno 2007.

\section{Themes and topics of old age and death in the poetry and prose by František Hrubín}

\section{Summary}

The article goes back to the prosaic and the poetic work by František Hrubín. The essay recalls poetry and segments of prose texts. Monitors the motifs and themes of old age and death. It quotes and interprets the verse, dominated by themes of time, aging, age as of a man from birth to death. Significant contrast is a man-child, an old man and a boy. We recognize the weight of the race, it determines the importance of grandfathers, fathers and grandsons. The death of grandfather determines the lives and values of grandson and of the young man. A man becomes a father, a man becomes a grandfather, a man remains forever a boy - are also determining the transformation work by František Hrubín. Old age and death are enduring a full part of human life.

Keywords: Czech literature of the 20th century, František Hrubín, poetry and prose, thema of old age, thema of death

\section{Мотивы и темы старости и смерти в поэзии и прозе Франтишка Хрубина}

Резюме

Статья возвращается к поэзии и к прозе Франтишка Хрубина, напоминает стихи и прозаические тексты, для которых центральными мотивами становятся старение и смерть. Мониторирует восприятие времени Хрубина, созревания, старения, возраст постепенной продолжительности человека от рождения до смерти. Цитирует и интерпретирует стихи, в которых преобладают темы времени, старения, старения - постепенной продолжительности человека от рождения до смерти. Значительные контрасты: человек-ребенок, старик-мальчик. Обнаружив вес семье, она определяет важность дедов, отцов и внуков. Смерть деда определяет жизнь внука и молодого человека. Человек становится отцом, человек становится дедушкой, человек навсегда останется мальчиком. Старость и смерть переживают полную часть человеческой жизни.

Ключевые слова: чешская литература ХХ века, тема смерти, тема старости, поэзия, проза, Франтишек Хрубин 